\title{
The Role of Stakeholders for Rural Community Development in Dealing with Globalization Competition in Era MEA Distributed Pelalawan
}

\author{
Herman \\ Public Administration Faculty of Social and Political Sciences Islamic University of Riau \\ Email: herman@soc.uir.ac.id
}

\begin{abstract}
This paper focuses on the issue of the role of stakeholders in the context of their participation in the development of rural communities so that the people in the village can grow in the face of competition in the era of MEA. The purpose of this paper is to know the extent of the role of stakeholders for rural community development in the face of globalization competition in the era of MEA in Pelalawan District. The theoretical approach that writers use that is adapted from various theories especially on the object of study is about the things that are considered important in solving the problems faced by rural society. The only thing that should be done by the government and corporate is to empower rural communities, build infrastructure and develop tourism. And ultimately the authors hope there is contribution of thought from the author useful for government and corporate in order to empower rural communities to be able to compete in the era of MEA
\end{abstract}

Keyword: MEA, Role, Stakeholder, Empowerment

\section{INTRODUCTION}

\section{Background Issues}

At the beginning of the idea of the implementation of the MEA is predicted to be done in 2020 through the Meeting in Bali in 2003 which was attended by Asean member countries of which are Indonesia, Malaysia, Singapore, Thailand, Laos, Myanmar, Philippines, Vietnam, Brunei Darussalam and Cambodia. However, this changed after a meeting in the Philippines conducted in 2007 where the contents of the meeting discussed the agreement of Asean member countries to accelerate the implementation of the MEA.

Asean Economic Community (AEC) is a discourse among Asean countries in order to face the free market which eliminates the tax or customs and freedom of a country to enter its goods to the country other. The purpose of the implementation of the MEA the author of quotation from MEA book Malang Regency are: 1. To improve the stability of the economy in the Asean region. 2. The creation of Asean free market area. [4]

The implementation of MEA is not only happening in the State, but also on Regional, Local, and Rural Scopes. Therefore, the role of government from various levels must be maximized in order to face the world of MEA era.

In Pelalawan District itself, the issue of MEA implementation has been meticulously responded by the Government of Pelalawan Regency as contained in the news online newspaper Thursday 28 October 2015 entitled "Pelalawan Ready to Face MEA", and one of the quotes is: We are ready to face the free market especially the MEA by the end of 2015, "said Regent Pelalawan, Muhammad Harris in the launch of Small Micro Business License (IUMK), and Submission of Copyrights and Submission of Cooperative Certificate by Minister of Cooperatives and SMEs, in Pangkalan Kerinci, capital of Pelalawan regency (http://www.beritasatu.com/nasional/260383-pelalawan siap hadapi mea.html) [6]

To realize the implementation of the MEA in Pelalawan District, there needs to be support from various fields, especially from the local government, the corporation (corporate), and the community itself, which of the three is a series called with stakeholders who must work together to realize the purpose of what agreed.

In accordance with the theme of the writer's paper that holds about the participation of stakeholders for rural community development in facing globalization competition in MEA era in Pelalawan Regency, it is better we first know little about Pelalwan District profile itself. Pelalawan Regency is one of the districts in Riau Province which is the result of pemekaran from Kampar regency which was inaugurated on October 12, 1999. Pelalawan Regency consists of 12 subdistricts and consists of 110 villages and villages. [5]

With the rapid development of Pelalawan Regency especially in the capital of Pangkalan Kerinci which is the base of Industry, where in Pangkalan Kerinci City there are some big companies either cross local or national. One of the largest national companies in the city of Pangkalan Kerinci is Riau Andalan Pulp and Paper (RAPP) company that moves the commodity pulp from raw materials to semi-finished. To stretch his business of course RAPP has subsidiaries of companies scattered throughout the village and district in Pelalawan District, one of which is PT. SAU located in Pelalawan District.

As a large company, RAPP is obliged to carry out corporate social responsibility known as corporate social responsibility (CSR). According to the World Business Council for Sustainable Development (WBCSD) corporate social responsibility or Corporate Social Responsibility is defined as a business commitment to contribute to sustainable economic development, in collaboration with employees and their representatives, their families, local communities and the general public to improve the quality of life in ways that are beneficial both for their own business and for development. [3] 
According to Untung (2008), one of the factors that cause CSR implementation is human capital (community empowerment). Therefore, the right target for community empowerment in Pelalawan Regency is the main target of rural community which is supported by the local government. [10]

Empowerment according to Abu Hurairah (2008:28) comes from the English "empowerment" which is usually interpreted as leader.[2] In the sense of giving or increasing "power" (power) to a weak or disadvantaged society. Meanwhile, according to Adi Fahrudin (2012: 16) interpret empowerment as a way in which people, organizations and communities directed to be able to rule over his life.[1]

But it cannot be denied so far the empowerment efforts have not been seen clearly, either the role of the government of the pelalawan district as well as from the corporate itself. This feels very sad because it is feared rural communities cannot compete for the future by the era of MEA. Efforts to implement the empowerment of rural communities the aim is to improve and improve the living standards and social conditions of the village community which is the largest part of Indonesian society, involving three parties, namely government, private and villagers.

\section{Purpose of Writing}

The purpose of this paper is: to know the extent of the role of stakeholders for the development of rural communities in the face of globalization competition in the era of MEA in Pelalawan District.

\section{DISCUSSION}

To face the era of this MEA, the government to do policy whose purpose is to address the competition by issuing Presidential Decree No. 37 of 2014 and Presidential Instruction No. 6 of 2014 on Improving Competitiveness in Order to Facing the ASEAN Economic Community.

As is known in the era of this MEA, there are things that are not limited are the flow of goods, service flow, capital flow, investment flows and trained labor. Responding to that, then what Pelalawan Government has done so far is to fortify with labor local regulation a whose purpose is to empower local workforce, then it must also be supported by all corporate in Pelalawan District. Furthermore, for more details about the discussion in the material of this paper can be seen as follows below:

\section{Empowerment of Human Resources in Rural Areas}

One of the factors that support the smooth work of an organization is human resources or known as HR. In order for the human resources to work and compete wherever they are, it is necessary to be empowered through education and training. One of the implementation by local government of Pelalawan Regency is by stipulating local regulation Pelalawan Regency Number 18 Year 2001 which then revised by Local Regulation Number 03 Year 2005 which one of its contents is to give $60 \%$ local power to be employed in companies in Pelalawan regency. But the implementation is not the case, the company in Kerinci District Pelalawan District that is PT. RAPP itself takes more outsiders from Pelalawan District to be employed. What is very worried again for the future if this is not anticipated by the local government then one-time foreign workers who have more skill will cause local community displacement because of the inability to compete with foreigners.[7]

Community empowerment when it comes to the above context is just a discourse of community empowerment in general, not to mention how the empowerment of society in the countryside done by the government and corporate. According to the authors' understanding, what is done to empower rural communities is by prioritizing their awareness to be active in the world of education or going to high school. Of course this should be supported by the government and the corporation, for example from the Pelalawan district government established several universities in the Capital of Pangkalan Kerinci where the curriculum of the education is based on MEA so that the society can compete for the future. In addition, to support empowerment through education, the thing done by the government and corporate is to provide scholarships to the less fortunate communities so that they do not drop out of school. It is certain that the scholarships given are the responsibility of the local government, but the company must also be responsible to the community. Moreover, this scholarship is a CSR activity.

Empowerment of rural communities is also done by digging the potential in the village to be used as Small and Medium Enterprises. So far, the response from the government has only been the launch of Small Micro Business License (IUMK), and Submission of Copyrights and Submission of Cooperative Certificate. But the most fundamental thing is to explore the unique potential of handicrafts that are considered to be able to compete with products outside the Pelalawan District is not excavated. So it is very unfortunate because if the business can be encouraged and empowered then the people in rural areas will be able to compete from the efforts they do. So once again the task of the Government of Pelalawan District through the relevant agencies to explore these potentials.

\section{Building Infrastructure}

In order to successfully implement the MEA, other things that also affect the implementation is to build infrastructure in all fields. In Pelalawan District itself many infrastructures are still left behind when compared with other regencies in Riau Province mainly from road and electric power development. Almost all villages, especially in Pelalawan District consisting of Rangsang Village, Sering and Sungai Ara are still far from the information from the government (PLN). So far, they have enlightened themselves with village self-help which is only for the night lighting. The question is how the home industry (home industry) can run well if the operational machine for the industry is only done at night while the day cannot be operationalized. So this needs special handling from the local government.

In addition to electricity, road infrastructure is also very alarming in the villages in Pelalawan District. as is known, to run the wheels of the economy so smoothly that the access road or transportation should be better again.

\section{Tourism development}

Do you know Bono Tour? This tour is only in Pelalawan District. According to the writer of this tour is less attention by 
the local government. Access to this tour is taken with two alternatives through the river (water) and by land (road). To access through the road is still very alarming, to take this tour from Bono Pekanbaru city can reach 5-6 hours journey. As is known that this tour is a pride tour that has been worldwide So this should also be considered well by the local government. On the other hand, the authors see many tours in Pelalawan District is not a priority but prioritized its development by the Government of Pelalawan District. Therefore, in this case the government must be observant in seeing which things should be prioritized and optimized its development so that the condition of tourism in Pelalalawan Regency more stretched again and more global again.

Other than that, if the tourism is well managed then it is believed the home industry will wriggle like sofenir, clothes, handicrafts that all smelled of tourist bono, So in this case is expected to need good government attention in order to promote this wisaata or maintain the sustainability of the tour.

\section{CONCLUSION}

Era MEA has been started since December 2015 yesterday, but the people of Riau Province, especially Pelalawan regency not ready to face it. Balum there is a careful anticipation of how to overcome the waves of labor from foreign, empowering the village community and prioritize the original products of a unique village and able to compete in the market. Even more concerning about education, infrastructure development and tourism development still looks weak. Therefore it needs serious handling for local and corporate governments. In the future, it is expected that the government and corporates in Pelalawan District will work together in order to build the society in general and the village community in particular so that they will be able to compete in facing the era of MEA. In addition, the most important thing to do is to provide socialization to the community so they more know again what is MEA.

\section{REFERENCES}

[1] Fahrudi, Adi, Pengantar Kesejahteraan Sosial. Bandung. PT. Refika Aditama, 2012

[2] Hurairah, Abu, Pengorganisasian dan Pengembangan Masyarakat Model dan Strategi Pembangunan yang Berbasis Kerakyatan. Bandung: Humaniora, 2008

[3] Mardikanto, Totok, CSR. Alfabeta, Bandung, 2014

[4]http:/ / bappekab.malangkab.go.id/downloads/BUKU\%20MEA\%20 2015.pdf.

[5] http:/ / Wikipedia.com (Kabupaten Pelalawan).

[6]http://www.beritasatu.com/nasional/260383-pelalawan siap hadapi mea.html.

[7] Peraturan Daerah Kabupaten Pelalwan Nomor 18 Tahun 2001 Tentang Penempatan dan Pemanfaatan Tenaga Kerja Lokal Bagi Peruhsahaan.

[8] Peraturan Daerah Kabupaten Pelalwan Nomor 03 Tahun 2005 Tentang Perubahan Nomor 18 Tahun 2001 Tentang Penempatan dan Pemanfaatan Tenaga Kerja Lokal Bagi Peruhsahaan.

[9] Suhendra, Peran Birokrasi Dalam Pemberdayaan Masyarakat. Bandung: alfabeta, 2006

[10]Untung, Budi Hendrik, Corporate Social Responsibility. Sinar Grafika, Jakarta, 2008 